\title{
INSTRUMEN ANGKET SELF-ESTEEM MAHASISWA DITINJAU DARI VALIDITAS DAN RELIABITAS
}

\author{
Rina Dwi Setyawati ${ }^{1}$, Nurina Happy ${ }^{2}$, Yanuar Hery Murtianto ${ }^{3}$ \\ 1,2,3Prodi Pendidikan Matematika Universitas PGRI Semarang
}

\begin{abstract}
One of the important thing in a study is instrument. There are several forms of instruments that can be used to measure student's self-esteem. One of them is a questionnaire. Self-esteem Questionnaire developed to measure the aspects of selfesteem, i.e: significance, competence, power, and virtue. Validity evidenced from the self-esteem questionnaire includes content validity and construct validity. Content validity is evidenced in face validity and logical validity. Validation results on the content validity are appropriate questionnaire to be used after 2, 3, 5, $6,8,9,10,11,13,14,15,26,29$, and 30 revised. The result of construct validity is model factor as a whole according to $\mathrm{p}$-Chi-Square $>0.05, \mathrm{RMSEA} \leq 0,08, \mathrm{NNFI}>$ $0,9, \mathrm{CFI}>0,9$, and IFI $>0,9$. The test results of these parameters individually show each path having a value of $t>1.96$ so that the paths are significant. This can be interpreted as a fit model factor and does not need to be done. Calculation of selfesteem questionnaire results obtained reliability $r_{X X^{\prime}}=0,83$ and standard error measurement $\hat{\sigma}_{E}=s_{E}=4,34$. The value in question is the self-esteem questionnaire score of the student is likely to be 4.34 points above or below the actual score.
\end{abstract}

Keywords: self esteem, self esteem questionnaire

\begin{abstract}
Abstrak
Salah satu modal penting dalam suatu penelitian adalah instrumen. Ada beberapa bentuk instrument yang dapat digunakan untuk mengukur self-esteem mahasiswa. Salah satunya adalah angket. Angket self-esteem yang dikembangkan mengukur aspek significance, competence, power, dan virtue. Validitas yang dibuktikan dari instrument angket self-esteem ini meliputi content validity dan construct validity. Validitas yang dibuktikan pada content validity meliputi face validity dan logical validity. Hasil validasi pada content validity adalah instrumen layak digunakan setelah butir 2, 3, 5, 6, 8, 9, 10,11, 13, 14, 15, 18, 19, 21, 23, 24, 26, 29, dan 30 dilakukan revisi. Hasil dari construct validity adalah model factor secara keseluruhan fit dengan p-value Chi-Square $>0,05$, RMSEA $\leq 0,08$, NNFI $>0,9$, CFI $>0,9$, dan IFI $>0,9$. Hasil pengujian parameter estimasi secara individual menunjukkan setiap jalur memiliki t-value >1,96 sehingga jalur-jalur signifikan. Hal tersebut dapat diartikan bahwa model factor fit dan tidak perlu dilakukan modifikasi. Perhitungan hasil uji coba angket self-esteem diperoleh koefisien reliabilitas $r_{X X^{\prime}}=0,83$ dan standard error measurement $\hat{\sigma}_{E}=s_{E}=4,34$. Nilai tersebut bermakna bahwa skor angket self-esteem siswa kemungkinan akan berada 4,34 poin di atas atau di bawah skor sebenarnya.
\end{abstract}

Kata kunci: self-esteem, instrumen angket self-esteem

Universitas PGRI Semarang

Email: rinadwisetyawati@upgris.ac.id
C2017 Universitas Islam Negeri Walisongo ISSN: 2088-7868, e-ISSN 2502-5708 


\section{PENDAHULUAN}

NCTM (2000) menetapkan pemecahan masalah sebagai suatu tujuan dan pendekatan. Memecahkan masalah bermakna menjawab suatu pertanyaan dimana metode untuk mencari solusi dari pertanyaan tersebut tidak dikenal terlebih dahulu. Untuk menemukan solusi, siswa harus menggunakan hal-hal yang telah dipelajari sebelumnya dan melalui proses dimana mereka akan mengembangkan pemahamanpemahaman matematika baru. Memecahkan masalah bukanlah hanya suatu tujuan dari belajar matematika tetapi sekaligus merupakan alat untuk melakukan proses belajar itu.

NCTM menempatkan kemampuan pemecahan masalah sebagai tujuan utama dari pendidikan matematika. NCTM mengusulkan bahwa: (1) pemecahan masalah haruslah menjadi fokus dari matematika sekolah dan pembelajaran matematika harus diorganisir melalui pemecahan masalah, sebagai suatu metode dari penemuan dan aplikasi, (2) menggunakan pendekatan pemecahan masalah untuk menyelidiki dan memahami konten matematika, dan (3) membangun pengetahuan matematika baru melalui pemecahan masalah.

Kesuksesan dalam melakukan pemecahan masalah dipengaruhi oleh banyak faktor. Salah satunya adalah self-esteem seseorang. Self-esteem menjadi perhatian yang sangat penting karena menurut Young \& Hoffmann (2004) self-esteem berhubungan dengan sejumlah faktor kehidupan, salah satu diantaranya kesuksesan siswa di kelas. Lawrence (2006) menambahkan siswa dengan self-esteem tinggi cenderung percaya diri dalam situasi sosial yang dihadapi dan percaya diri dalam menangani tugas-tugas yang diberikan oleh guru. Selain itu, siswa dengan self-esteem tinggi tersebut akan mempertahankan rasa keingintahuannya secara alami dalam belajar serta memiliki semangat dan antusias ketika menghadapi tantangan baru. Sebaliknya, siswa dengan self-esteem rendah justru menghindari situasi dimana situasi tersebut berpotensi membuat dirinya merasa malu dihadapan orang lain. Siswa dengan self-esteem rendah cenderung lebih memilih dihukum atau mungkin dipandang sebagai seorang "jagoan" oleh teman-temannya dibandingkan terlihat bodoh.

Pernyataan tersebut diperkuat dari hasil penelitian Neny \& Nurahma (2012) yang mengungkapkan bahwa terdapat korelasi yang signifikan dan positif antara selfesteem dan prestasi belajar, yaitu sebesar 0,591. Hasil tersebut mengungkapkan bahwa semakin tinggi self-esteem pada siswa akan semakin tinggi pula prestasi belajar siswa 
tersebut. Selain itu, hasil uji koefesien determinasi sebesar 34,89\% yang artinya variabel prestasi belajar ditentukan sebesar $34,89 \%$ dari variabel self-esteem siswa. Hasil penelitian Ginintasari, Suherman, \& Pujasari (2007) juga mengungkapkan hasil uji korelasi antar variabel diketahui secara berurutan bahwa harga diri (self-esteem) berkorelasi positif Prestasi Akademik (0,483 dengan p. $<0,01)$, sedangkan nilai selfesteem dengan aspek dan sub-aspek pembangunnya memiliki nilai korelasi positif dengan p. $<0,01$.

Meskipun self-esteem memiliki peranan yang cukup penting pada pribadi seseorang berkaitan dengan prestasi atau kesuksesan belajarnya di kelas, namun selfesteem jarang diperhatikan. Untuk itu perlu dilakukan penelitian bagaimana profil kemampuan mahasiswa dalam melakukan pemecahan masalah ditinjau dari self-esteem mahasiswa.

Terdapat banyak pendapat terkait definisi self-esteem. Reece, Brandt, \& Howie (2011: 78) mengungkapkan self-esteem adalah perasaan kecukupan seseorang dalam banyak peran yang telah dilakukannya dalam hidup. Tak terkecuali perannya sebagai seorang anak, remaja, bahkan sebagai seorang siswa atau mahasiswa. Lebih lanjut Lawrence (2006: 5) mengatakan self-esteem sebagai penilaian seseorang terhadap kesenjangan antara self-image (kesadaran seseorang terhadap karakteristik mental dan fisik dirinya yang diperoleh dari hasil refleksi dan tafsiran seseorang terhadap pengalaman dan lingkungannya) dan ideal-self (karakteristik ideal yang harus ditunjukkan oleh seseorang). Hal tersebut sejalan dengan pendapat Plummer (2005: 13) bahwa self-esteem diindikasikan dengan adanya perbedaan antara apa yang dirasakan seseorang dan ideal diri.

Coopersmith yang dikutip Muijs \& Reynolds (2011: 179) mendefinisikan selfesteem sebagai penilaian pribadi tentang kelayakan yang ditunjukkan dengan sikap individu terhadap dirinya sendiri. Penilaian yang dibuat seseorang berkaitan dengan dirinya ditunjukkan melalui sikap setuju atau tidak setuju. Hal tersebut mengindikasikan sejauh mana orang tersebut menyakini bahwa dirinya mampu, penting/berarti, sukses, dan layak/pantas/berguna. Lebih lanjut Coopersmith mengungkapkan terdapat empat dasar dari self-esteem yaitu kemampuan (competence), keberartian (significance), kebaikan (virtue), dan kekuatan (power). Berdasarkan hal tersebut seseorang akan menilai diri sesuai dengan seberapa mahir dirinya dalam melaksanakan tugas, seberasa 
baik dirinya memenuhi standar etika atau agama, seberapa dicintai atau diterima dirinya oleh orang lain, dan seberapa banyak kekuatan yang dapat ia dikerahkan (Murk, 2006: 111).

Dalam rangka mengukur tinggi rendahnya self-esteem seseorang, peneliti perlu membuat instrumen untuk mengukur self-esteem. Lawrence (2006: 54) menyarankan dua langkah yang diperlukan untuk membuat instrumen yang mengukur self-esteem. Langkah pertama adalah menentukan terlebih dahulu aspek self-esteem apa yang akan diukur, global self-esteem atau specific self-esteem. Langkah selanjutnya adalah menentukan metode tertentu untuk mengukur self-esteem. Pemilihan metode ini perlu dilakukan dengan hati-hati karena terdapat beberapa kesulitan ketika mengukur selfesteem siswa.

Kesulitan yang akan ditemui dalam mengukur self-esteem dijelaskan oleh Lawrence (2006: 54-55) yaitu (1) kurangnya kesadaran yang dimiliki siswa dalam memahami dirinya sendiri, (2) bahasa yang digunakan dapat dimaknai berbeda oleh siswa, dan (3) seringkali siswa memberikan respon yang sesuai dengan yang diharapkan guru tetapi tidak mencerminkan keadaannya yang sebenarnya. Lawrence (2006: 56) menambahkan bahwa tidak ada instrumen yang sempurna untuk mengukur self-esteem karena terdapat keterbatasan pada setiap instrumen yang dibuat. Tetapi, Lawrence mengungkapkan terdapat beberapa tipe yang disarankan untuk mengukur tinggi rendahnya self-esteem seseorang, diantaranya: Behavioral Checklist, Questionnaire, Rating Scale, Adjectival Discrepancies dan Semantic Differential, Q-sort, Projective Technique, dan Personal Interview.

Berdasarkan beberapa pendapat di atas, self-esteem ini mengacu pada specific self-esteem dalam matematika, sehingga self-esteem didefinisikan sebagai penilaian individu terhadap kemampuannya dalam pembelajaran matematika dan kelayakannya bagi teman sebaya dan dosen, serta ditunjukkan melalui sikap yang dilakukan terhadap dirinya sendiri dalam pembelajaran matematika. Instrumen yang akan dikembangkan untuk mengukur tinggi rendahnya self-esteem dalam makalah ini adalah angket atau questionnaire.

Angket self-esteem mahasiswa digunakan untuk mengukur self-esteem siswa pada matematika. Angket terdiri dari 32 butir pernyataan dengan alokasi waktu 10 menit. Pilihan respon yang diberikan adalah "Sangat Setuju”, "Setuju”, "Ragu-ragu", 
"Tidak Setuju", dan "Sangat Tidak Setuju" pada 11 butir pertama, sedangkan pada 21 butir berikutnya adalah "Selalu", "Sering", "Kadang-Kadang", "Jarang", dan "Tidak Pernah". Kisi-kisi angket self-esteem dapat dilihat pada tabel 1 berikut.

Tabel 1 Kisi-Kisi Angket Self-Esteem Siswa

\begin{tabular}{|c|c|c|c|}
\hline \multirow{2}{*}{$\begin{array}{c}\text { Aspek yang } \\
\text { Diukur }\end{array}$} & \multirow{2}{*}{ Indikator } & \multicolumn{2}{|c|}{ Nomor Pernyataan } \\
\hline & & + & 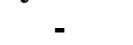 \\
\hline \multirow[t]{2}{*}{ Significance } & $\begin{array}{l}\text { Menunjukkan keyakinan bahwa dirinya berarti bagi } \\
\text { orang lain }\end{array}$ & 6,10 & 24,26 \\
\hline & $\begin{array}{l}\text { Menunjukkan keyakinan bahwa dirinya dapat diterima } \\
\text { oleh orang lain }\end{array}$ & 2,31 & 20,27 \\
\hline \multirow[t]{2}{*}{ Competence } & $\begin{array}{l}\text { Menunjukkan keyakinan terhadap kemampuannya pada } \\
\text { pelajaran matematika }\end{array}$ & 1,5 & 15,21 \\
\hline & $\begin{array}{l}\text { Menunjukkan keyakinan bahwa dirinya mampu } \\
\text { memecahkan masalah matematika }\end{array}$ & 16,9 & 14,29 \\
\hline \multirow[t]{2}{*}{ Power } & $\begin{array}{l}\text { Menunjukkan kemampuan untuk mengontrol diri pada } \\
\text { situasi yang dihadapi }\end{array}$ & 12,18 & 19,32 \\
\hline & Menunjukkan kesadaran pada diri sendiri & 3,8 & 13,11 \\
\hline \multirow[t]{2}{*}{ Virtue } & $\begin{array}{llllll}\begin{array}{l}\text { Menunjukkan } \\
\text { matematika }\end{array} & \text { sikap yang positif } & \text { dalam belajar } \\
\end{array}$ & 4,22 & 17,7 \\
\hline & $\begin{array}{l}\text { Menunjukkan kesungguhan dalam memecahkan } \\
\text { masalah matematika }\end{array}$ & 23,25 & 28,30 \\
\hline \multicolumn{2}{|c|}{ Banyaknya pernyataan } & 16 & 16 \\
\hline
\end{tabular}

Dalam rangka membuat profil kemampuan pemecahan masalah ditinjau dari self-esteem mahasiswa, diperlukan suatu instrumen yang dapat mengukur self-esteem mahasiswa yang valid dan reliabel. Suatu instrumen dikatakan valid bila dapat mengukur apa yang seharusnya diukur melalui item-item instrumen. Mardapi (2016:32) menunjukkan bahwa ada lima sumber bukti validitas yang penting yaitu, bukti berdasarkan isi tes, bukti berdasarkan proses respons, bukti berdasarkan hubungan dengan variable lain, dan bukti berdasarkan konsekuensi pengujian. Pembuktian validitas instrumen dapat digunakan validitas isi dan validitas konstruk.

\section{METODE PENELITIAN}

Prosedur untuk memperoleh validitas isi (content validity) adalah dengan membandingkan isi dengan spesifikasi tes atau non-tes yang menggambarkan domain yang diukur. Terdapat dua hal yang diperhatikan yaitu validitas muka (face validity) yang meliputi tampilan dari instrumen dan validitas logis (logical validity) yang meliputi kerepresentativan instrumen pada domain yang diukur (Allen \& Yen, 1979: 96). Setelah instrumen disusun berdasarkan teori, selanjutnya dikonsultasikan dengan 
ahli yang berkompeten di bidang yang bersangkutan. Validitas konstruk menunjukkan sejauh mana alat ukur mengungkapkan suatu konstruk teoritis yang hendak diukurnya (Allen \& Yen, 1978: 108) dan diperoleh dengan melakukan uji coba.

Nurkancana dalam Matondang (2009) menyatakan bahwa suatu alat pengukur dapat dikatakan alat pengukur yang valid apabila alat pengukur tersebut dapat mengukur apa yang hendak diukur secara tepat. Dalam hal validitas dan reliabilitas, tentunya dipengaruhi oleh (1) instrumen, (2) subjek yang diukur, dan (3) petugas yang melakukan pengukuran. Dalam hal pengukuran, khususnya dalam pendidikan tentunya yang terpenting adalah informasi hasil ukur yang benar. Sebab dengan hasil ukur yang tidak atau kurang tepat maka akan memberikan informasi yang tidak benar, sehingga kesimpulan yang diambil juga tidak benar.Reliabilitas alat penilaian adalah ketepatan atau keajegan alat tersebut dalam menilai apa yang dinilai, hal ini dinyatakan oleh Sudjana (2004:16). Hasil yang relatif yang sama kan diperoleh pada saat melakukan penilain ini. Reliabilitas juga menunjukkan derajat kekonsistenan hasil/nilai mahasiswa pada pemberian penilaian yang berulang (Nitko \& Brookhart, 2011 : 64). Suatu tes dikatakan reliabel jika selalu memberikan hasil yang sama bila diteskan pada kelompok yang sama pada waktu atau kesempatan yang berbeda, hal ini pun juga disampaikan oleh Arifin (1991: 122). Pada angket self-esteem koefisien reliabilitas diestimasi menggunakan rumus Alpha Cronbach sebagai berikut:

$$
r_{X X^{\prime}} \geq \alpha=\left[\frac{N}{N-1}\right]\left[\frac{S_{X}^{2}-\sum S_{i}^{2}}{S_{X}^{2}}\right]
$$

Keterangan:

$X=$ Skor amatan tes dibentuk dari $N$ komponen, $X=\sum_{i=1}^{N} Y_{i}$

$S_{X}^{2}=$ varian sampel $X$

$S_{Y_{i}}^{2}=$ varian sampel skor amatan pada komponen ke- $i$

$N=$ banyaknya komponen yang dikombinasi untuk membentuk $X$

Selanjutnya dilakukan perhitungan standard error measurement dengan mengasumsikan bahwa standard error measurement $\left(\sigma_{E}\right)$ setiap mahasiswa sama maka estimasi $\hat{\sigma}_{E}$ dapat digunakan, yaitu

$$
\hat{\sigma}_{E}=s_{E}=s_{x} \sqrt{1-r_{X X^{\prime}}}
$$

Keterangan:

$s_{x}=$ standar deviasi 


\section{HASIL DAN PEMBAHASAN}

\section{Validitas Instrumen}

a. Validitas Isi

Menurut Mardapi (2016:33) Untuk menunjukkan bukti validitas berdasarkan isi dapat diperoleh dari suatu analisis hubungan antara isi tes dan konstruk yang ingin diukur. Kita bisa melihat isian tes yang mengacu pada tema, kata-kata, format butir, tugas, atau pertanyaan pada tes. Sedangkan menurut Aswar (2012: 111) validitas yang dibuktikan pada validitas isi ini meliputi validitas muka dan validitas logis. Validitas muka meliputi tampilan dari instrumen, sedangkan validitas logis meliputi kerepresentativan instrumen pada domain yang diukur. Ahli dalam penelitian ini yang diminta untuk membuktikan validitas ahli ini adalah Dr. Ali Mahmudi dan Dr. Sugiman yang merupakan dosen dari Universitas Negeri Yogyakarta.

Hasil validasi instrumen angket self-esteem menunjukkan pernyataan nomor 2, $3,5,6,8,9,10,11,13,14,15,18,19,21,23,24,26,29$, dan 30 perlu direvisi. Pernyataan yang sudah direvisi kemudian dikonsultasikan lagi dengan kedua validator, sampai instrumen angket layak digunakan. Menurut Heynes et al. dalam Azwar ( 2012) validitas isi mempunyai makna sejauh mana elelem-elemen dalam suatu instrumen unkur benar-benar relevan dan merupakan representasi dari kontruk yang suasi denngan tujuan pengukuran.

\section{b. Validitas Konstruk}

Validitas konstruk menunjukkan sejauh mana alat ukur mengungkapkan suatu konstruk teoritis yang hendak diukurnya (Allen \& Yen, 1978: 108) dan diperoleh dengan melakukan uji coba. Uji coba instrumen angket self-esteem dilakukan pada seluruh mahasiswa semester 1 yang berjumlah 101 mahasiswa.

Validitas konstruk angket self-esteem diperoleh dengan melakukan analisis data hasil uji coba dengan menggunakan confirmatory factor analysis. Analisis faktor ini digunakan untuk mengonfirmasi struktur model atau faktor yang telah diasumsikan sebelumnya. Tahap pertama yang dilakukan dalam confirmatory factor analysis adalah membentuk model faktor. 
Model faktor yang dibentuk pada self-esteem disajikan pada gambar 1. Model faktor yang telah terbentuk kemudian dinilai atau dievaluasi kecocokan modelnya secara keseluruhan (assess the overall model fit). Uji kecocokan model ini dilakukan untuk menunjukkan apakah model yang diusulkan mampu menghasilkan estimasi matriks kovarians populasi yang berbeda atau tidak dengan matriks kovarians data sampel. Hasil pengujian kecocokan model secara keseluruhan dengan menggunakan LISREL disajikan ada tabel 2 berikut.

Tabel 2. Uji Kecocokan Model secara Keseluhan

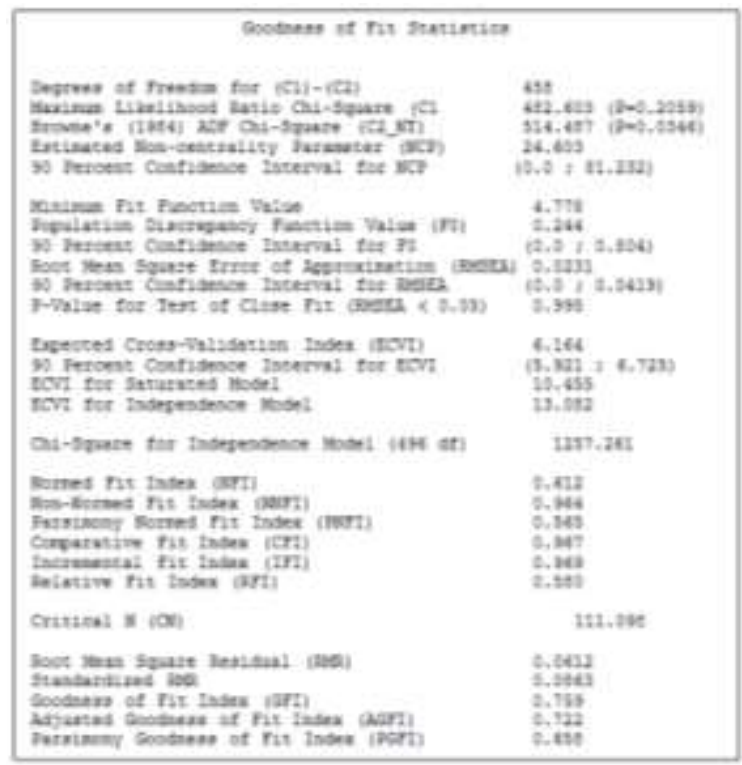

Rangkuman tabel 2 disajikan pada tabel 3 berikut.

Tabel 3. Rangkuman Hasil Pengujian Model secara Keseluruhan

\begin{tabular}{lccl}
\hline $\begin{array}{l}\text { Statistik } \\
\text { Uji }\end{array}$ & Kriteria & Hasil & Kesimpulan \\
\hline $\begin{array}{l}\text { Chi- } \\
\text { Square }\end{array}$ & $\begin{array}{c}\text { p-value } \\
>0,05\end{array}$ & 0,21 & Model cocok \\
\hline $\begin{array}{l}\text { RMSE } \\
\text { A }\end{array}$ & $\leq 0,08$ & 0,02 & Model cocok \\
\hline NFI & $>0,9$ & 0,61 & Model tidak cocok \\
\hline NNFI & $>0,9$ & 0,96 & Model cocok \\
\hline CFI & $>0,9$ & 0,97 & Model cocok \\
\hline IFI & $>0,9$ & 0,97 & Model cocok \\
\hline RFI & $>0,9$ & 0,58 & Model tidak cocok \\
\hline GFI & $>0,9$ & 0,76 & Model tidak cocok \\
\hline AGFI & $>0,9$ & 0,72 & Model tidak cocok \\
\hline & & & \\
\hline
\end{tabular}


Berdasarkan tabel 3 terdapat 4 statistik uji yang menyimpulkan model tidak fit, sedangkan terdapat 5 statisik uji yang menyimpulkan model fit, yaitu p-value ChiSquare $>0,05, \quad$ RMSEA $\leq 0,08, \quad$ NNFI $>0,9, \quad$ CFI $>0,9$, dan IFI $>0,9$. Jadi, dapat disimpulkan bahwa model faktor secara keseluruhan fit.

Setelah menguji model faktor secara keseluruhan, selanjutnya dilakukan uji pada setiap parameter estimasi dengan uji-t. Hasil pengujian dengan LISREL disajikan pada tabel 2. Hasil pengujian parameter estimasi secara individual pada tabel 2 menunjukkan bahwa setiap jalur memiliki t-value $>1,96$ sehingga dapat simpulkan bahwa jalur-jalur tersebut signifikan. Oleh karena itu, model faktor fit dan tidak perlu dilakukan modifikasi.

Berdasarkan uraian hasil pengujian di atas dapat disajikan perbandingan kisi-kisi instrumen self-esteem secara teoritik dan empiris yang disajikan pada tabel 4 berikut.

Tabel 4 Kisi-Kisi Instrumen Self-Esteem secara Teoritik dan Empiris

\begin{tabular}{cccc}
\hline \multicolumn{2}{c}{ Konstruk Self-Esteem secara Teori } & \multicolumn{2}{c}{$\begin{array}{c}\text { Konstruk Self-Esteem secara } \\
\text { Empiris }\end{array}$} \\
\hline \multicolumn{1}{c}{ Aspek } & No. Butir & Aspek & No. Butir \\
\hline Significance & $6,10,24,26,2,31,20,27$ & Significance & $6,10,24,26,2$, \\
& & & $31,20,27$ \\
Competence & $1,5,5,21,16,9,14,29$ & Competence & $1,5,15,21,16$, \\
& & & $9,14,29$ \\
Power & $12,18,19,32,3,8,13,11$ & Power & $12,18,19$, \\
& & & $32,3,8,13,11$ \\
Virtue & $4,22,17,7$ & Virtue & $4,22,17,7$ \\
& $23,25,28,30$ & & $23,25,28,30$ \\
\hline
\end{tabular}

Tabel 4 di atas menunjukkan bahwa konstruk self-esteem secara empiris sesuai dengan konstruk self-esteem secara teori.

Hal ini dapat diartikan bahwa aspek validitas dan relibilitas dapat menjelaskan berbagai teknik operasional yang mendukung rigoritas (ketepatan) data yang dihasilkan dalam penlitian kualitatif yaitu kredibilitas, dependabilitas, konfirmabilitas, validitas sesuai dengan yang dinyatakan Afiyanti, Y. (2008). Cronbach \& Meehl (1995) dalam Yuniarti dan Sunarto (2016) menyatakan bahwa untuk membuktikan validitas konstrak dapat dilakukan melalui: mengartikulasikan serangkaian konsep teoretik dan interrelasinya, mengembangkan cara untuk mengukur konstrak hipotetik yang diteorikan, dan (3) 
menguji secara empirik hubungan hipotetik di antara konstrak tersebut dan manifestasinya yang nampak.

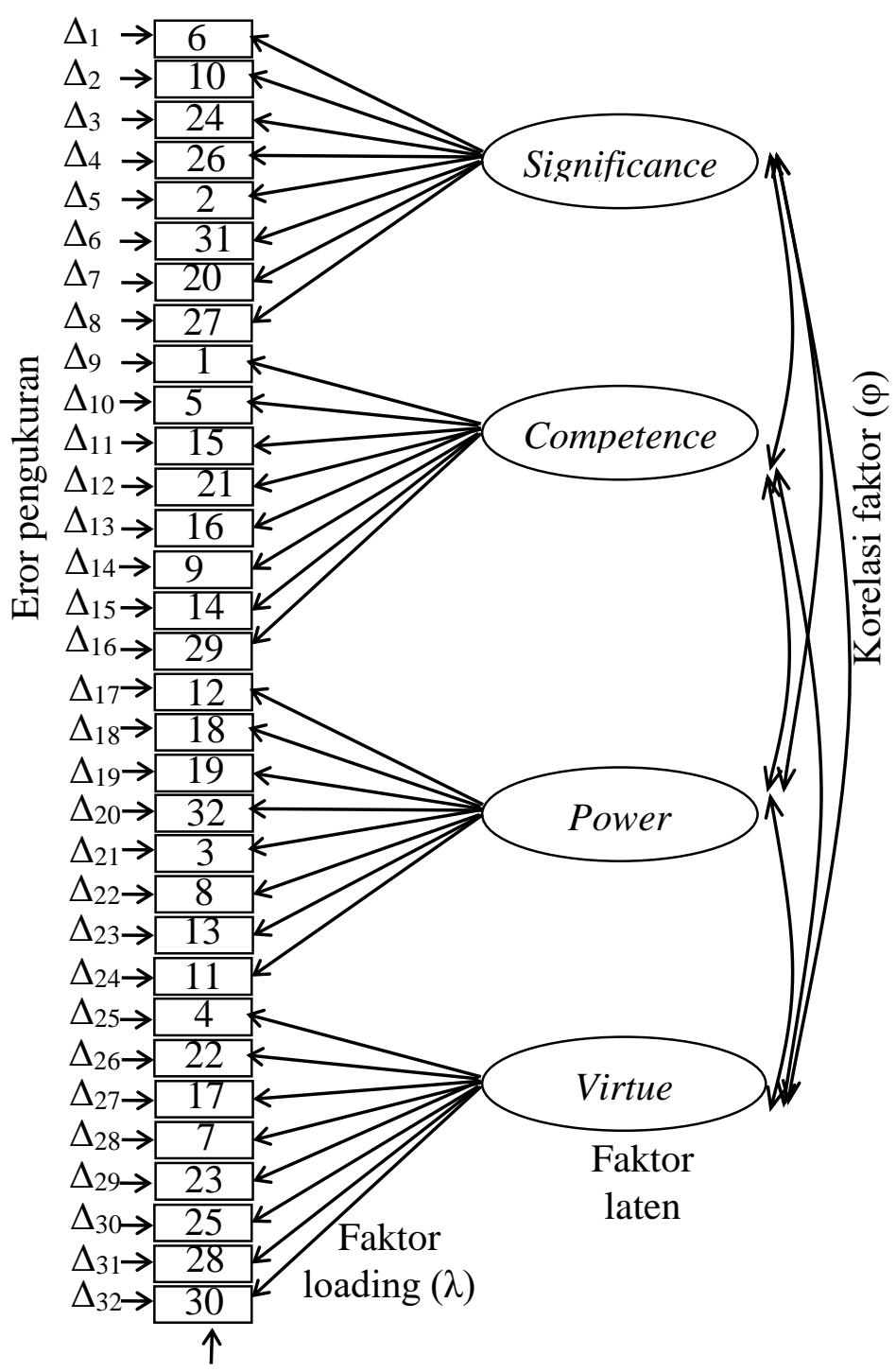

Variabel yang diobervasi/Pernyataan

Gambar 1

Model Faktor yang Dibentuk 


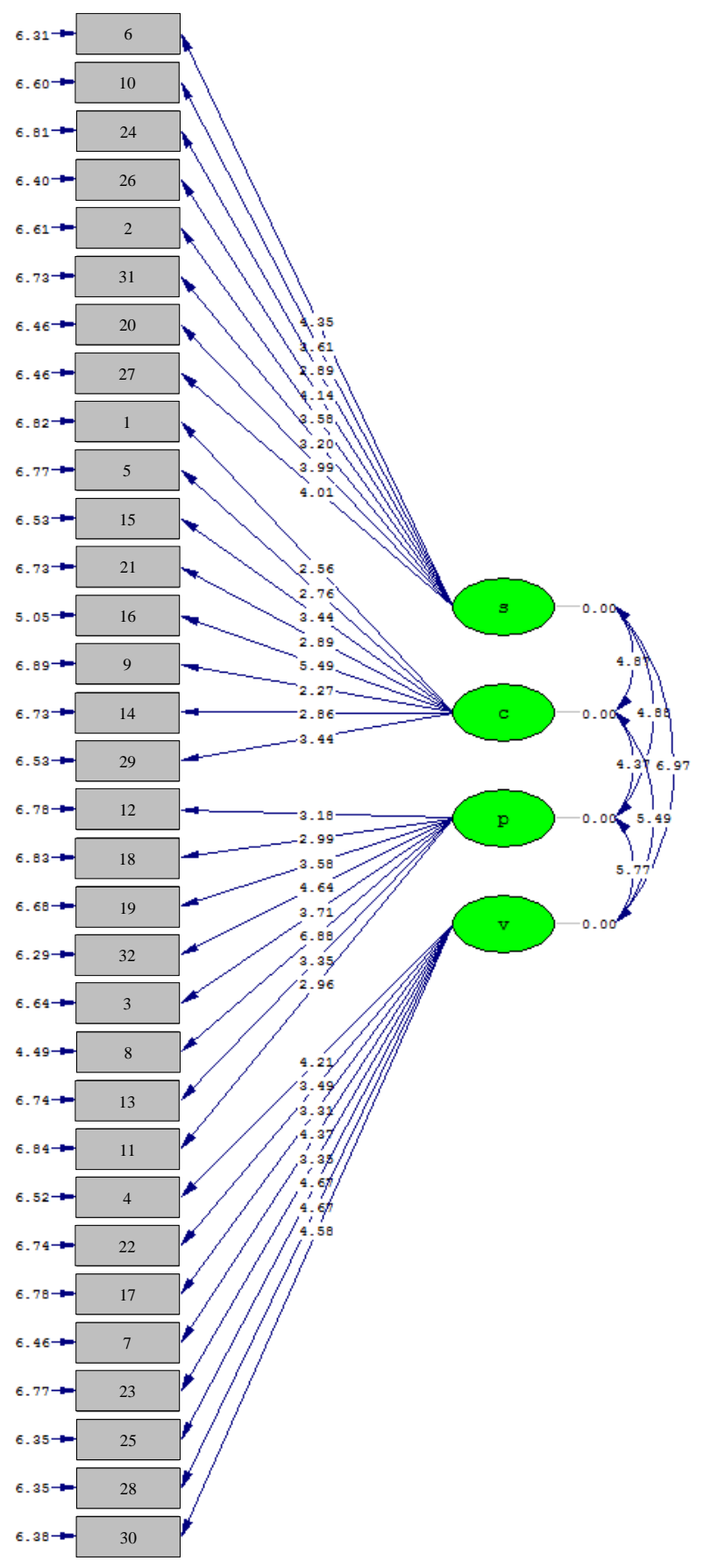

Gambar 2

Hasil Uji Masing-Masing Parameter Estimasi

\section{Reliabilitas Instrumen}

Reliabilitas menunjukkan derajat kekonsistenan hasil/nilai siswa pada pemberian penilaian yang berulang (Nitko \& Brookhart, 2011 : 64). Perhitungan hasil uji coba angket self-esteem diperoleh koefisien reliabilitas $r_{X X^{\prime}}=0,83$ dan standard error 
measurement $\hat{\sigma}_{E}=s_{E}=4,34$. Nilai tersebut bermakna bahwa skor angket self-esteem siswa kemungkinan akan berada 4,34 poin di atas atau di bawah skor sebenarnya. Matondang (2009) menyatakan bahwa interpretasi terhadap koefisien reliabilitas merupakan intrepretasi relatif dalam artian bahwa tidak ada batasan mutlak yang menunjukkan berapa angka koefisien minimal yang harus dicapai agar suatu pengukuran dapat disebut reliabel. Namun, memberikan informasi tentang hubungan varians skor teramati dengan skor sejati kelompok individu. Hal ini juga disampaikan Azwar (2003 : 176) bahwa instrumen pengukuran yang baik merupakan salahasatu karakter utama pada pelaksanaan uji reliabilitas.

\section{SIMPULAN DAN SARAN}

Hasil validasi dari instrumen self-esteem pada content validity adalah instrumen layak digunakan setelah butir 2, 3, 5, 6, 8, 9, 10, 11, 13, 14, 15, 18, 19, 21, 23, 24, 26, 29, dan 30 dilakukan revisi. Hasil dari construct validity adalah model factor secara keseluruhan fit dengan p-value Chi-Square $>0,05, \mathrm{RMSEA} \leq 0,08$, NNFI $>0,9, \mathrm{CFI}>0,9$, dan IFI $>0,9$. Hasil pengujian parameter estimasi secara individual menunjukkan setiap jalur memiliki t-value>1,96 sehingga jalur-jalur signifikan. Hal tersebut dapat diartikan bahwa model factor fit dan tidak perlu dilakukan modifikasi. Perhitungan hasil uji coba angket self-esteem diperoleh koefisien reliabilitas $r_{X X^{\prime}}=0,83$ dan standard error measurement $\hat{\sigma}_{E}=s_{E}=4,34$. Nilai tersebut bermakna bahwa skor angket self-esteem siswa kemungkinan akan berada 4,34 poin di atas atau di bawah skor sebenarnya.

\section{DAFTAR RUJUKAN}

Allen, M. J., \& Yen, W. M. (1979). Introduction to measurement theory. Monterey: Brooks/Cole Publishing Company.

Afiyanti, Y. (2008). Validitas dan reliabilitas dalam penelitian kualitatif. Jurnal Keperawatan Indonesia, 12(2), 137-141

Azwar, Saifuddin. Sikap Manusia Teori dan Pengukurannya. Liberty: Yogyakarta, 1988.

Lawrence, D. (2006). Enhancing self-esteem in the classroom( $3^{\text {rd }}$ ed.). London: Paul Chapman Publishing

Mardapi, Djemari.(2016). Pengukuran, penilaian dan evaluasi pendidikan.Yogyakarata :Parama Publishing 
Matondang, Z. (2009). Validitas dan reliabilitas suatu instrumen penelitian. Jurnal Tabularasa, 6(1), 87-97.

Muijs D., \& Reynolds, D. (2011). Effective teaching: Evidence and practice (3 ${ }^{\text {rd }}$ ed.). Los Angeles: SAGE.

Murk, C. J. (2006). Self-esteem research, theory, and practice: Toward a positive psychology of self-esteem ( $3^{\text {rd }}$ Ed.). New York: Springer Publishing Company, Inc.

Nitko, A. J., \& Brookhart, S. M. (2011). Educational assessment of students. Boston, MA: Pearson Education, Inc.

Plummer, D. (2005). Helping adolescents and adults to build self-esteem. London: Jessica Kingsley Publishers.

Reece, B. L., Brandt, R., \& Howie, K. F. (2011). Effective human relations: Interpersonal and organizational applications ( $\left.7^{\text {th }} e d.\right)$. Mason, $\mathrm{OH}$ : SouthWestern Cengage Learning.

Sudjana, Nana, 2004). Penilaian Hasil Proses Belajar Mengajar, Bandung: Remaja Rosdakarya.

Yuniarti, S dan Sunarto (2016) Validitas Konstrak Instrumen Evaluasi Outcome Lembaga Pendidikan Guru Vokasional. Jurnal Penelitian dan Evaluasi Pendidikan, Volume 20, No 2, Desember 2016 (221-233) 